\title{
Exploring Students' Skills and Attitudes on Effective Use of ICTs: Case Study of Selected Tanzanian Public Secondary Schools
}

\author{
Alcardo Alex Barakabitze*, Edvin J. Kitindi, Camilius Sanga, George Kibirige, Noel Makwinya \\ Faculty of Science (FoS), Sokoine University of Agriculture (SUA), Tanzania
}

Copyright $(\mathcal{C} 2015$ by authors, all rights reserved. Authors agree that this article remains permanently open access under the terms of the Creative Commons Attribution License 4.0 International License

\begin{abstract}
This study was conducted purposely following various initiatives and programmes by the Government of Tanzania to incorporate ICT in education since 2007 with the National ICT policy theme "ICT for improved education". The study provides insights regarding secondary school students' skills and attitudes in effective use of information and communication technology. The study was a co-relational and cross-sectional survey biased to the quantitative approach involving students, ICT teachers and school administrators. A total of 246 students from six public secondary schools in Tanzania were involved in this study. Primary data were collected using a self-administered questionnaire. Using inferential and descriptive analyzes, results show that, secondary school students do not have enough skills on effective use of information and communication technologies. However, students have basic knowledge in different aspects of ICTs particularly Internet and various hardware and software available in Tanzania. The implications to the approach of teaching and learning of ICT subjects in secondary schools, its evaluation and assessment and future initiatives related to ICT educations and infrastructure development have impacts towards creating a well-connected society. It is therefore recommended that secondary schools should provide enough ICT tools for students' hands-on experiences. The utmost end result of integrating ICT in secondary education system will eventually be the economic engine of Tanzania by preparing her students for the knowledge based economy.
\end{abstract}

Keywords ICTs, Secondary Education Students, Computer Literacy, Attitude, Public Secondary Schools, Tanzania

\section{Introduction}

Traditionally, in a pre-technology education context, the teacher remained a sole source and sender of knowledge through "chalk-and-talk" method[6].Students were thus mere recipients of teacher's instructions thereby characterizing classrooms with insufficient interaction. It is the growth of Information and Communication Technologies (ICTs) which has dramatically reshaped teaching and learning processes in education [67] [56]. Mbaeze et al.[37] highlights that ICTs are generally accepted as a modern instrumental tool that enables the educators to modify the teaching methods they use in order to increase the students performance. Many educational institutions around the world are adopting ICT as a tool of teaching and learning as well as offering ICT related academic programs because of integrating human society in information and communications. ICT for Education (ICT4E) is more critical today than ever before since its growing power and capabilities are triggering a change in the available learning environments [54].

Volman et al.[80] and de Corte et al.[11] narrates that, the effective use of ICT offers powerful learning environments and can transform the learning and teaching process so that students can deal with knowledge in an active, self directed and constructive way. ICTs should be used to develop students' skills for cooperation, communication, problem solving and lifelong learning[55].Burniske et al.[8] show that students with competence in ICT will be able to serve as worthy citizens in their communities by understanding how society operates in the current competitive knowledge economy era. However, Hindi et al. [24] point out that students who do not have skills in ICT are likely to encounter more challenges with the increased workplace demands for computer literate employees [79].

The integration of ICT in secondary education does promote autonomous learning, curriculum differentiation, student (learner)-centred learning, higher order thinking, problem-solving, personalized learning and collaborative (cooperative) learning[4]. The integration of ICT in secondary education has a potential to facilitate the 
acquisition of students relevant life skills that buttress the development process in the prevailing economic and information era[36][65].ICT provides an enabling environment for developing countries to compete with the developed countries than ever before. In this era, Tanzania need to integrate ICT in education to enhance access, equity, quality and relevance basic education, while stimulating and improving problem solving based learning, experiential learning and lifelong learning.

\subsection{Statement of the Research Problem}

Since 2002, the Government of Tanzania through the Ministry of Education and Vocational Training (MoEVT)[41] with the inputs of educational stakeholders and other partners has been conceptualizing and implementing various ICT policies and initiatives related to ICT4E[22]. With such initiatives in place, one would expect a fully-fledged integration of ICT in Tanzanian schools today. However, despite the availability of ICT tools in the schools, previous studies conducted show that few teachers and students are using ICT as a teaching and learning tools [75][44]. Very interestingly, many studies stress that in many schools ICTs are mostly confined to administration, and personal use [40][44][75][74][22][82][23][71][25][48]. $\quad$ Although different ICT programmes and Governmental policies clearly are already in place to integrate ICT in the educational sector, there are still challenges and gaps in implementation. According to Swarts \&Washira [71], the challenges can be categorized into access, equity, quality and ICT relevance. This shows that, careful investigation of the current teaching and learning practices, readiness, skills, competence, knowledge and attitude of various educational stakeholders, specifically on student's perspectives regarding the use of ICTs in schools is needed so as to understand the pedagogical value of ICT in Tanzanian PSS today. Many researchers investigated the use of ICT4E from teachers' viewpoints; hence there is a need for study which focuses on students' viewpoints. This is the knowledge gap which this study seeks to fill by exploring student's skills, knowledge and attitudes towards the use of ICTs in secondary schools.

\subsection{Significance and Study Objectives}

The importance of ICT in education in Tanzanian Education started early 2000s. Different policy documents of the Government of the United Republic of Tanzania provide emphasis towards an integration of ICT in all sectors of development including education. Examples of policy documents include: the Poverty Reduction Strategy Paper (2000), the Tanzania Vision 2025, the Education Sector Development Programme (1998), the Teacher Education Master Plan (2000), Secondary Education Master Plan (2000), ICT Policy for Basic Education (2007), the Higher Education Sub-Master Plan (2003-2018), and the National ICT Policy (2003)[26][33].These Government policy documents have in common, the strategic point focus, which stress the need to use ICT as a tool to improve access and the quality of delivery of education and training at all levels (pre-primary school, primary school, secondary school, advanced secondary school, colleges, university and working places)[33].Thus, ICT4E is meant for primary education, secondary education, colleges / university education, formal and in formal adult education.

It is well known that, if ICTs tools are properly taught and used, they could play an important role in restructuring the learning-instruction processes in a way that can help to determine students' academic success. It is from this premise that the significance of this study arise. Therefore, the significance of this study is towards informing students' readiness towards effective use of available ICTs in their schools. This study is expected to contribute to the understanding of the current status of students regarding the use of ICT4E in public secondary schools (PSS) by policy makers, curriculum developers and implementers. In a long run, this will help them to realize how best they can integrate ICT in the current secondary education curriculum. The curriculum must include ICT topics related to practical, technical and social as well as moral and professional ethical values.

In summary, the overall objective of this research study was to explore the students' ICT skills and attitudes from selected PSS in Tanzania. Specifically, the study intended:

a) To analyze secondary school students' ICT skills

b) To examine how they are using ICT.

c) To identify students' attitudes towards ICT.

d) To determine to what extent the students actively adopt the use of ICT in learning.

e) To assess challenges which hinder the adoption of ICT to the students.

f) To establish strategies that could overcome the challenges identified in (e).

From these specific objectives, the ultimate outcome is to encourage the participation of students, teachers, and other educational stakeholders in education and training in PSS to use effectively ICTs in teaching and learning processes.

\section{Literature Review}

Tanzania installed and started using the first computer in the Ministry of Finance in 1965[38]. From 1985 onwards, there has been a high influx of computers due to the country's liberalization policies and value added tax (VAT) exemption on computers [39]. Recognizing the potential of ICT as a significant tool for improving education delivery, outcomes and impact, the MoEVT embarked on the development of an ICT Policy for Education in 2006 which adopted the national ICT policy of 2003. A multi-stakeholder process for the provision of policy advice was done in 2006 to the MoEVT on ICT, resulted in an ICT guideline (also referred to as 'White Paper') called 
'Thinking through the use of ICT in Secondary Education in Tanzania - Deliberations of a multi-stakeholder work group on education" [22][71][41].

It provided input to the national ICT Policy for Basic Education launched in 2007 which covers basic education of pre-primary and primary, secondary and teacher education as well as non-formal and adult education and university education. The policy document was developed to guide the integration of ICT in basic education [71]. According to the National Report of the United Republic of Tanzania on the Development of Education (2008, P.8), the MoEVT, through the ICT Policy aims

"to empower learners, teachers, education managers and leaders to use ICT judiciously and effectively for expanding learning opportunities and ensuring educational quality and relevance".

The Tanzania Development Vision 2025[19] also puts a great emphasis on the role that ICT can play in development arena and specifically, ICT4E. It is noted in the Tanzania Vision 2025 that ICT can be used as a

"central to competitive social and society economic transformation".

Despite having good policy document in ICT, its implementation in PSS is still very low. However previous studies show that private secondary schools are more resourced with ICT facilities than Government PSS [66]. Hare [22] points out that, most private secondary schools in the urban centers, especially Dar es Salaam, are already using ICTs, albeit without a formal setting or a policy framework. In addition, the study by Ndibalema[48] shows that there is lack of knowledge on how to use ICT as pedagogical tool among the secondary school teachers. Despite the availability of ICT tools in some of the schools, it is evident that ICT is rarely used [66] and only few teachers and students use them as a teaching and learning tool[40][44].In some schools, ICTs are mostly confined to administration with limited use for teaching basic ICT skills [22] and in other schools, ICT tools are not used at all[75]. Therefore in most PSS, ICTs has not taken recognition to be used as a medium of instruction in teaching and learning. In order for ICT to have recognition in teaching and learning, a number of different ICT4E initiatives that have been introduced in the country [85]. These initiatives have been delivering ICT infrastructure to schools, mainly at secondary level $[40][48][68,69][75][82][71][74]$. These ICT4E initiatives have been supported by the Government of Tanzania, Non Governmental Organization (NGOs), parents and other development agencies[17] as well as the East Africa Cooperation Federation[83]. The main aim of many ICT4E initiatives has been to improve education at all levels from pre- primary to higher education institutions in the country as explained in the following section.

\subsection{ICT4E Initiatives in Secondary Schools}

The use of ICT in Tanzanian schools started in the 1960s and since 1970s, PSS students have been listening and watching to different educational programmes through radios and Televisions. These educational programmes have been designed by the MoEVT by collaborating with Radio Tanzania [44].Currently, TBC One and Star TV broadcast programmes on various subjects in secondary schools in English.

According to Tilya[74], in 2002 the Ministry of Education with support from the International Institute for Communication and Development (IICD) initiated seven projects, of which the aim was to improve the teaching and learning processes in PSS in Tanzania through ICTs. These seven projects were meant to carry different mandates in providing ICT services in PSS as described below:

- Distance Education Learning Services: this project deals with developing ICT facilities for teaching and learning purposes [22].

- The Bright Education Trust Fund: this project deals on how to use ICTs for teaching and learning and school administration [74].

- TanEdu Educational Website: this project deals with displaying relevant PSS information on the website.

- Wanafunzi (Student) Website: This project deal with deployment of website which enable students to exchange their knowledge on different subjects.

- The Tanzania Computer Literacy for Secondary Schools Trust Fund (TCLSS): This project was meant to provide computers and establish secondary school computer laboratories.

- The Model School Project: This project meant to enable secondary schools located in remote areas to use ICTs. It also promoted students' learning using ICTs among secondary school students.

- ICT-Connect-TED: This project provided training on how to use ICT in order to enhance students' ICT knowledge and skills. It also connected all Teachers' Training Colleges (TTCs) in the country.

The e-Schools forum which consists of a number of stakeholders of ICT4E was formed in 2005[22]. It was meant to provide ICT facilities in secondary schools including access to the Internet, help schools and the ministry in adopting the Education Management Information System (EMIS); and helping ICT policy makers in developing the curriculum and online content for secondary schools[22][71]. According to Hare [22] and Nyirenda [85], this initiative was conducted in two phases: The first phase involved two hundred secondary schools while the second phase involved two thousand secondary schools. Currently, the project is being implemented in secondary schools which are near to the national power grid and those schools with more than two teachers who have been trained in ICT and eager to participate in the project [25].

The NoPC pilot project is an IT solution that provides ICT education facilities to all sectors involved in the provision of education (schools, public universities and libraries) for free 
in the developing countries [25].The project in Tanzania targets to supply ICT facilities to two hundred secondary schools which are close to TTCs. The intention is to improve the process of teaching subjects like STEM[25] It is expected that the NoPC will transform the current traditional computing and greatly reduce the computer maintenance needs.

According to Hare [22] and Simba et al. [68], the Barclays Bank in cooperation with the Digital Links International initiated a project which was meant to support the teaching and learning process in East African countries including Tanzania. This project intended to supply ten thousand computers in five hundred secondary schools by collaborating with public organizations in each country. It has been reported that in 2009 , one hundred computers have been distributed in five secondary schools in Tanzania [71]. In Tanzania, community tele-centers are among the initiatives which provide the ICT access like Internet facilities to some primary and secondary schools. NGOs have been providing more than one thousand computers in secondary schools and the Tanzania Education Authority (TEA) has also provided ICT facilities in seven secondary schools in the country [41].According to MoEVT,[41], secondary schools located in remote areas in some districts are being piloted with a sustainable broadband connectivity model such that remote schools in Tanzania can have Internet access for enhancing teaching and learning processes. The sustainable broadband connectivity model is currently piloted in Bunda, Serengeti and Bagamoyo districts [41].

Furthermore, the University of Dar Es Salaam (UDSM) has a project called TanSSe-L which intend to develop electronic learning (e-learning) system for remote secondary schools in Tanzania [68,69].Another initiative has been implemented by the National Examination Council of Tanzania (NECTA) and aimed at giving examinations to students taking ICT studies as their optional subject in order to equip them with relevant ICT skills and knowledge. In addition, the national examination results are put on-line in the NECTA Website (http://www.necta.go.tz) for the public to be informed and to enable students to view their examinations results. The success in implementation of the above mentioned ICT4E initiatives depends on the availability of competent teachers in ICT. This is the basis that any ICT project to PSS must go hand in hand with implementation of ICT at TTCs as highlighted in the next section.

\subsection{ICT4E Initiatives in TTCs}

The MoEVT and Mid-Sweden University (Mi-Un) which is very experienced in providing distance education, flexible learning and training for teachers developed a project known as ICT-BITES for in-service teachers in secondary schools [25]. This project aims at providing ICT training to secondary school teachers on the subject specialization and equips them with the required pedagogical skills. The project is being sponsored by the Information and Communication Technology programme from Sweden (SPIDER) with complementary support from the Open University of Tanzania (OUT) and UDSM. In addition, this project also aims at providing short course training to teachers which is based on ICT and tailored to teachers in their particular subject area. Furthermore, the project intends to offer a certificate course in ICT pedagogy for teachers at Aga Khan University. The teachers will learn how to use ICTs in order to support teaching and learning [25][71].According to Hooker et al.[25], in 2005, the MoEVT with support from the Swedish International Development Agency (SIDA) formulated another project to introduce ICTs in TTCs. This project intended to improve teacher's education quality and competency for both student-teachers (pre-service) and in-service teachers. This project was completed in 2008 and all thirty four TTCs were provided with thirty thin-client computers and a server and other ICT accessories. The project also provided ICT training to tutors and college administrators. Tutors were taught on how to use ICTs in order to enhance the teaching- learning process in their colleges and two to four tutors from all 34 colleges were trained in CISCO IT essentials[71][34].In 2011, the MoEVT implemented another project titled 'Teacher Development for 21st Century (TDev21)'. It was a pilot project under joint support from the World Bank and Global e-Schools and Communities Initiative (GESCI) of which the aim was to contextualize and pilot global ICT competency standards for teachers in Tanzania[25].The teachers' competency framework for Tanzania was adopted on multiple global standards including the global ICT-CST framework by UNESCO[76], the International Society for Technology in Education (ISTE) framework (USA), the European Teacher Competency and Qualifications Framework (eTQF) (EU), the National Center for Technology in Education (NCTE)'s e-Learning Roadmap (Ireland), the ICT-enhanced Teacher Standards (Africa), and Raising the Standards framework (Australia)[25]. Currently, the TDev21 pilot project in Tanzania is being implemented by MoEVT and supported by the World Bank and Global e-Schools and Communities Initiative (GeSCI)[25].

The Government of Tanzania in 2006 established the Universal Communications Access Fund (UCAF) through integration of different policies such as the National Telecommunications Policy (1997), National ICT Policy (2003), and the Declaration of Principles of the World Summit on the Information Society-WSIS) of 2003 (Geneva) and 2005 (Tunisia) [84]. The intention of the access fund is to enable accessibility and participation by communication operators in Tanzania in provision of communication infrastructure and services, with a view to promoting ICT4E in all sectors and economic development of the rural and urban under-served areas [28].

According to WSIS (2005)[84] and as cited in MoEVT[41], Tanzania is among the signatories to the World Summit on the Information Society(WSIS) declaration of principles and action plan, with the aim of building a 
people-centred, information and development-oriented society. WSIS mission for education which is to be achieved by 2015, include: "connecting universities, colleges, secondary schools and primary schools with ICT; adopting all primary and secondary school curricula to meet the challenges of the Information Society". However, the MoEVT in partnership with the Camara International Organization (CIO) has formulated a new strategy known as 'Tanzania Beyond Tomorrow (TBT) which has been in implementation from 2011-2020 with the aim of harmonizing different ICT4E initiatives [25].The TBT intends to improve the basic education delivery in Tanzania with great emphasis on improved education access, equity and quality education to all students in secondary school levels. Key objectives of TBT are namely:

"to provide harmonization and integrate all ICT4E initiatives into one unified framework, enhancing the appropriate use of ICT in education, improving ICT infrastructure in secondary schools in order to support the teaching-learning process at a basic level"[25].

Cantafio[32] highlights that this programme intends to address 4000 secondary schools and 1.5 million students. TBT is working to streamline and embrace many different projects that already exist. Some of the programs are: Ncomputing-(Yet to engage), the NoPC project, BridgeIT, Yes I Can and the Powering Potential (NY Based) which is developing $17 \mathrm{~W}$ computing systems in Tanzania. The Powering Potential is a low power computing initiatives and can use solar equipment to run the computing systems off the grid in the rural areas within the country [32].

Although different ICT programmes and Governmental policies clearly are already in place to integrate ICT in the educational sector, there are still challenges and gaps in implementation. According to Swarts and Washira[71] these challenges can be categorized into access, equity, quality and ICT relevance. Some of the challenges and possible solutions are identified and listed in Table 1.

Mwalongo[44] also stresses that, there are many ICT4E initiatives in such a way one would expect secondary schools in Tanzania to be fully-fledged with ICT facilities. But still many schools have got many challenges (Table 1). Students are not equally ICT literate in both urban and rural areas as there is obvious evidence of the digital divide between students in urban and rural areas of Tanzania[18][64][65]. The study by Sedoyeka and Gafufen [65] identified challenges and opportunities for ICT in secondary schools. They recommended the need to operationalise ICT policy in all secondary schools in Tanzania. Ndibalema[48] researched on the altitude of teachers in using ICT as a pedagogical tool and found that many teachers are not aware of the potentials of ICT in education. A recent study by Muhoza et al.[46] confirmed earlier results of other researchers [18][64][65] who mentioned factors that hinder the use of ICT4E. Sedoyeka and Gafufen[65] categorized factors hindering ICT4E in PSS into the following aspects: lack of policy for schools, inadequate administration and total implementations of ICT project on the level of schools, access to ICT, inadequate school management of ICT initiatives and poor school leadership and culture, lack of ICT infrastructure for teachers' training, lack of different Governmental policies awareness among teachers, lack of teachers' readiness towards pedagogical skills for electronic and blended learning. From literature review, many researchers investigated the use and factors hindering ICT4E from teachers' viewpoints; hence there is a need for study which focuses on students' viewpoints [46].In order to accomplish the study objectives; the following research questions guided the study.

a) What is the level of competence of students on commonly used ICT tools and software?

b) What is the altitude of students towards ICT and their belief regarding its usefulness?

c) What is the student's knowledge in different aspects of ICT?

d) What are the factors affecting students towards ICT use in secondary school?

e) Will there be a difference between the attitude, skills and knowledge of male and that of female students on the use of ICTs in their academic life?

f) Will there be a difference between the attitude, skills and knowledge of Ordinary-level(O-level) and that of Advanced-level(A-level) students on the use of ICTs?

Based on the research questions, the following hypotheses were formulated:

Hypothesis 1: There is no significant difference between ICT skills of male and that of female students in their academic life.

Hypothesis 2: There is no significant difference between the attitude of male and that of female students on the use of ICTs in their academic life.

Hypothesis 3: There is no significant difference between the knowledge of male and that of female students on the use of ICTs in their academic life.

Hypothesis 4: There is no significant difference between the attitude, skills and knowledge of O-level and that of A-level students on the use of ICTs. 
Table 1. Major education challenges and how ICT could address them in PSS (adapted from Swarts and Washira,[71]

\begin{tabular}{|c|c|c|c|c|}
\hline Category & Challenges in education & How ICT can address challenges & $\begin{array}{c}\text { Progress made using } \\
\text { ICT to address } \\
\end{array}$ & Challenges in using ICT \\
\hline Access & $\begin{array}{l}\text { - Limited number of } \\
\text { classrooms } \\
\text { accommodate students. } \\
\text { - Limited number of } \\
\text { students proceeding in } \\
\text { subsequent levels of } \\
\text { education. } \\
\text { - Limited number of } \\
\text { educators in PSS. } \\
\text { - There are no clear } \\
\text { policies } \\
\text {-Lack of clear ICT for } \\
\text { students who need } \\
\text { intensive cares i.e. } \\
\text { disabled students. } \\
\text { Problems of distributing } \\
\text { and keeping track of } \\
\text { teacher's professional } \\
\text { development in PSS. }\end{array}$ & $\begin{array}{l}\text { - PSS can adopt and use ICTs to } \\
\text { supplement the current education delivery } \\
\text { system. The use of e-learning and } \\
\text { Mobile-learning, Radios and Television in } \\
\text { PSS has an advantage of providing training } \\
\text { to many teachers and increase access of } \\
\text { these ICTs to students. } \\
\text { - ICTs can help to facilitate the process of } \\
\text { distributing, deploying and track teachers' } \\
\text { professional development. This will be } \\
\text { possible if the MoEVT will have e- } \\
\text { databases of teachers which show their } \\
\text { specialization, qualifications and working } \\
\text { experience. }\end{array}$ & $\begin{array}{l}\text { - Massive investment in } \\
\text { national ICT } \\
\text { infrastructure (e.g. laying } \\
\text { of the national fibre optic } \\
\text { cable) } \\
\text { - Prominence given to } \\
\text { Education generally in } \\
\text { the national budget } \\
\text { - Provision of ICTs } \\
\text { resources in all } \\
\text { Government TTCs and } \\
\text { adopting teachers' } \\
\text { competency framework } \\
\text { from UNESCO. } \\
\text { - Some universities like } \\
\text { UDSM, SUA and OUT } \\
\text { has made a great } \\
\text { contribution by providing } \\
\text { ICT programmes in order } \\
\text { to reduce the ICT4E } \\
\text { gaps. }\end{array}$ & $\begin{array}{l}\text { - There are no strategies } \\
\text { and policies which focus in } \\
\text { introducing open-distance } \\
\text { learning for PSS in } \\
\text { Tanzania. } \\
\text { - Teachers, principals and } \\
\text { school administrators do } \\
\text { not know or are not aware } \\
\text { of other methods to } \\
\text { supplement the current } \\
\text { delivery education system. } \\
\text { - The need for large ICT4E } \\
\text { investments in PSS and } \\
\text { provide efficient models } \\
\text { which could assist in } \\
\text { integrating ICT in PSS. } \\
\text { - The deployment of ICTs } \\
\text { in PSS takes place in an } \\
\text { uncoordinated manner. }\end{array}$ \\
\hline Quality & 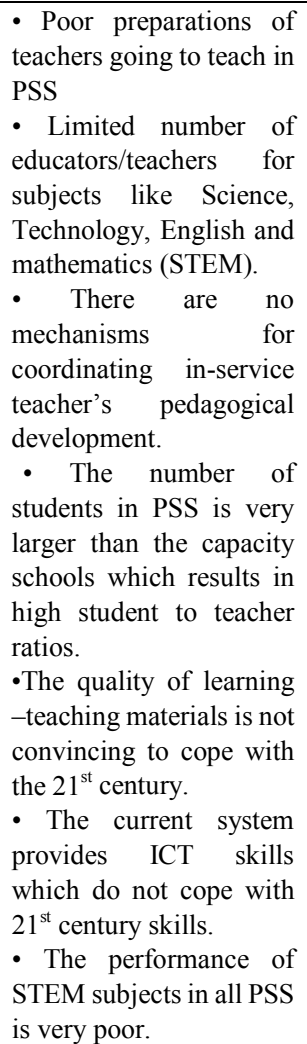 & $\begin{array}{l}\text { - Many teachers can be trained and provide } \\
\text { continuous academic development to } \\
\text { teachers using ICTs. } \\
\text { - ICT can be used in creating and delivering } \\
\text { enough content materials for learning and } \\
\text { teaching. } \\
\text { - The problem of overcrowded classes can } \\
\text { be solved by using ICTs. } \\
\text { - ICT can be used for motivating } \\
\text { learners/students through multi-media } \\
\text { content. } \\
\text { - ICT can be used in facilitating students' } \\
21^{\text {st }} \text { century skills. } \\
\text { - By using computer simulations, students } \\
\text { can understand easily difficult problems. } \\
\text { - School administrations and the general } \\
\text { management can be enhanced and } \\
\text { strengthened by using ICTs. } \\
\text { - Students who need special cares can be } \\
\text { provided and equipped with assistive } \\
\text { technologies (ATs). }\end{array}$ & $\begin{array}{l}\text { - Most of the effort for } \\
\text { ICT deployment in PSS } \\
\text { is still depending on } \\
\text { donors from NGOs and } \\
\text { private sectors } \\
\text { - Limited use of } \\
\text { technologies like radio } \\
\text { and m-learning to } \\
\text { support teacher's } \\
\text { pedagogical } \\
\text { development. } \\
\text { - ICTs are mostly } \\
\text { deployed in PSS to } \\
\text { support administration } \\
\text { through EMIS. } \\
\text { - All Governmental } \\
\text { training colleges are } \\
\text { currently equipping } \\
\text { teachers (pre-service) } \\
\text { with ICT skills. }\end{array}$ & $\begin{array}{l}\text { - Poor infrastructure in PSS } \\
\text { - Limited contents to be } \\
\text { used in PSS and other } \\
\text { learning institutions. } \\
\text { - Lack of enough efforts to } \\
\text { improve ICTs use and } \\
\text { open- distance education in } \\
\text { PSS. } \\
\text { - Although ICTs are } \\
\text { supplied for administration } \\
\text { purposes in PSS, their use } \\
\text { is very limited. } \\
\text { - Low integration and } \\
\text { implementation of ICTs for } \\
\text { learning and teaching in } \\
\text { PSS. }\end{array}$ \\
\hline
\end{tabular}




\begin{tabular}{|c|c|c|c|c|}
\hline Category & Challenges in education & How ICT can address challenges & $\begin{array}{c}\text { Progress made using } \\
\text { ICT to address }\end{array}$ & Challenges in using ICT \\
\hline Equity & $\begin{array}{l}\text { - The ratio of students: } \\
\text { reference book is very } \\
\text { high. } \\
\text { - Students with special } \\
\text { needs encounter } \\
\text { challenges related to } \\
\text { infrastructure to support } \\
\text { their learning and no } \\
\text { enough teachers to } \\
\text { support this group in } \\
\text { PSS. } \\
\text { - There are also gender } \\
\text { imbalance and disparities } \\
\text { in PSS }\end{array}$ & $\begin{array}{l}\text { - The group of students who need special } \\
\text { needs can be supported by ICT specifically } \\
\text { using ATs. } \\
\text { - ICT can provide alternative methods for } \\
\text { delivering education to students in PSS. } \\
\text { - The open-distance and electronic learning } \\
\text { education delivery systems can improve } \\
\text { and increase teachers' competency and } \\
\text { training. } \\
\text { - ICT can enable students and teachers to } \\
\text { collaborate and share different learning } \\
\text { experience and plan their studies in } \\
\text { different ways. } \\
\text { - ICT can provide efficient management of } \\
\text { PSS processes by using tracking systems } \\
\text { and e-databases. }\end{array}$ & $\begin{array}{l}\text { - The Tanzania } \\
\text { Development Vision puts } \\
\text { a great emphasis also on } \\
\text { ICT4E after realizing } \\
\text { the importance of } \\
\text { equipping students with } \\
\text { ICT knowledge and } \\
\text { prepare an information } \\
\text { society } \\
\text { - Efforts have been made } \\
\text { by developing the digital } \\
\text { content at Tanzania } \\
\text { Institute of Education } \\
\text { (TIE). }\end{array}$ & $\begin{array}{l}\text { - Problems related to } \\
\text { electricity, ICT facilities, } \\
\text { and Internet connectivity } \\
\text { especially for PSS located } \\
\text { in remote areas. } \\
\text { - The integration of ICTs in } \\
\text { PSS is mainly limited due } \\
\text { to low allocation of funds } \\
\text { for procuring ICTs in } \\
\text { secondary schools. } \\
\text { - Disabled students and } \\
\text { PSS in remote areas do not } \\
\text { take advantage of new } \\
\text { technologies. }\end{array}$ \\
\hline Relevance & $\begin{array}{l}\text { - Students' knowledge } \\
\text { economy has not been } \\
\text { facilitated because of } \\
\text { using outdated curricula } \\
\text { in learning and teaching } \\
\text { process. } \\
\text { - The current teaching and } \\
\text { learning methodologies } \\
\text { in PSS do not fosters the } \\
21 \text { st century skills. } \\
\text { - There are no } \\
\text { mechanisms for } \\
\text { Inadequate quality } \\
\text { assurance mechanisms }\end{array}$ & $\begin{array}{l}\text { - ICT can address the gaps by including } \\
\text { ICT skills in PSS student's curriculum. } \\
\text { - ICT can be used to provide the relevant } \\
\text { methods for delivering digital contents that } \\
\text { can demonstrate international best practice. } \\
\text { - ICT can be used in developing and } \\
\text { supporting the twenty first century } \\
\text { students' knowledge and skills. } \\
\text { - The teaching -learning process when is } \\
\text { integrated with ICT, it is likely to enable } \\
\text { students to learn anywhere and at anytime. } \\
\text {-ICT provides new opportunities and can } \\
\text { equip students with lifelong learning. }\end{array}$ & $\begin{array}{l}\text {-ICT curriculum has been } \\
\text { developed for teachers } \\
\text { and secondary } \\
\text { educations. } \\
\text { - Efforts in place to link } \\
\text { education industry } \\
\text { partners with VETA for } \\
\text { alignment of Vocational } \\
\text { education. }\end{array}$ & $\begin{array}{l}\text { - There are no clear } \\
\text { strategies for coordinating } \\
\text { and providing training to } \\
\text { PSS teachers who are } \\
\text { in-service. } \\
\text { - There is a high need of } \\
\text { education reform in } \\
\text { Tanzania so that all PSS } \\
\text { ICT curriculums can go in } \\
\text { line with the twenty first } \\
\text { century skills required. } \\
\text { - The education reform and } \\
\text { curriculum should also } \\
\text { comply with the } \\
\text { requirements of Tanzania } \\
\text { and International industry. }\end{array}$ \\
\hline
\end{tabular}

\section{Research Design and Methodology}

\subsection{Research Design and Procedure}

The major components of this section are the methodology, data collection methods, study population and sampling frame, research procedures and the methods for data analysis. The study aimed at exploring students' skills and attitudes on effective use of ICTs in public secondary schools in Tanzania. The study employed a mixed approach (quantitative and qualitative) study focusing in PSS in Tanzania.

A survey design approach adopted from Czaja et al.[10] was employed in the study. A questionnaire was designed and distributed randomly to students in the selected PSS. The questionnaire which consisted of seven questions and three sections was pretested in a pilot study to validate the data collection. Section A was designed to elicit demographic information of the study respondents such as age, sex and student's level of study. Section B was designed to elicit information on students 'skills on ICT tools available in their schools (consisted of 20 test items), information on students' attitudes/perceptions towards the use of ICT tools (consisted of 29 test items), and Students' knowledge in different aspects of ICTs (consisted of 9 test items). Section C was designed to elicit the challenges or factors that students encounter on using ICT tools while they are in schools. By using a 5-point likert-type scale which was ranging from strongly agree to strongly disagree, students were asked to indicate their agreement or disagreement with several statements/test items in questions from section B.

\subsection{Collection Methods}

\subsubsection{Primary Data Collection}

Primary data were collected through questionnaires, personal interviews and researcher's observation. Among secondary school stakeholders that were involved in interviews includes: ICT teachers and students. An assessment of the ICT tools available in the selected PSS was made through interviews with key informants such as ICT teachers/Trainers, students and school administrators. The willingness of different stakeholders (school policy makers, students, ICT teachers/trainers) in adopting the use of ICT tools in order to promote participation of teaching and learning process in secondary schools were explored through interviews.

\subsubsection{Secondary Data Collection}

Secondary data were collected by reviewing the relevant documents available in the selected PSS. Review of the schools' office plans was done to establish whether there are any ICTs implementations in secondary school subjects / courses. The use of questionnaires, interviews and 
observations provided the grounds for the thorough way of complementing the weakness of qualitative research methods from quantitative research methods (i.e. triangulation)[29].

\subsubsection{Study Population and Sampling Frame}

The population for research consisted of students enrolled in the selected study PSS. Head of the Department of ICT Education and ICT teachers in the selected schools were also involved in the study because they play a key role in the ICT equipment acquisition process to schools, ICT teaching, decision making and enforcement of policies as well as providing ICT implementation guidance to different stakeholders in schools. Non-probability sampling technique (purposive sampling) as done by Onwuegbuzie et al.[51] and Saunders et al[63] was employed in selecting PSSs because this technique ensures group size balancing if more than one group are to be selected. However, based on the researcher, this technique provides a deliberate selection of sample units that can conform to some predetermined criteria [5].In this study, the criterion which was predetermined was that, the school should have basic ICT facilities as well as teaching ICT subjects. A total of 246 students from Ordinary Level (Form/Level I to Form/Level IV) and Advanced Level (Form/Level V to Form/Level VI) were randomly chosen to participate in this study. The list of PSS involved in the study is listed in Table 2.

Table 2. The list of six public registered secondary schools

\begin{tabular}{|c|c|c|c|c|}
\hline No & $\begin{array}{c}\text { Name of } \\
\text { School }\end{array}$ & $\begin{array}{c}\text { School } \\
\text { Registration No }\end{array}$ & Region & Level \\
\hline 1 & Azania & S.8 & $\begin{array}{c}\text { Dar Es } \\
\text { Salaam }\end{array}$ & $\begin{array}{c}\text { Ordinary \& } \\
\text { Advanced } \\
\text { Level }\end{array}$ \\
\hline 2 & Kilakala & S.45 & Morogoro & $\begin{array}{c}\text { Ordinary \& } \\
\text { Advanced } \\
\text { Level }\end{array}$ \\
\hline 3 & Morogoro & S.13 & Morogoro & $\begin{array}{c}\text { Ordinary \& } \\
\text { Advanced } \\
\text { Level }\end{array}$ \\
\hline 4 & Pugu & S.282 & $\begin{array}{c}\text { Dar Es } \\
\text { Salaam }\end{array}$ & $\begin{array}{c}\text { Ordinary \& } \\
\text { Advanced } \\
\text { Level }\end{array}$ \\
\hline 5 & Kisutu & S.12 & $\begin{array}{c}\text { Dar Es } \\
\text { Salaam }\end{array}$ & $\begin{array}{c}\text { Ordinary } \\
\text { Level }\end{array}$ \\
\hline 6 & Zanaki & S.11 & $\begin{array}{c}\text { Dar Es } \\
\text { Salaam }\end{array}$ & $\begin{array}{c}\text { Ordinary \& } \\
\text { Advanced } \\
\text { Level }\end{array}$ \\
\hline
\end{tabular}

\subsubsection{Data Gathering Procedures}

After securing the research clearance from Sokoine University of Agriculture, researchers under this study visited the Governmental officials (District Commissioners (DCs) and the District Education Officers (DEOs)) in both districts to seek permission of collecting data from the selected PSS. After introducing the objectives of the study to respondents in selected PSS then questionnaires were administered to 246 students for data collection.

\subsubsection{Survey Instrument Testing}

In order to test the survey instrument's validity and reliability, the initial draft of survey was administered on 60 students from Kilakala Secondary School in Morogoro region. From this initial draft, the final instrument was revised and was tested for reliability using test-retest method for the interval of 2 weeks by computing the Cronbach's Alpha reliability coefficient from the collected data in the initial draft. According to Nunnaly [50], in order for the Cronbach's Alpha coefficient to be valid and reliable, it should be equal or greater than an acceptable cut-off value, which is 0.70 (i.e, $\alpha>=0.70$ ). Table 3 shows that the Cronbach's Alpha reliability coefficient of the questionnaire under this study was above an acceptable value in all sub-scales, that is: 0.875 under (students' skill and competences on commonly used ICT tools and software); 0.857 under (students' attitude towards ICT and their belief regarding its usefulness) and 0.837 under (students' knowledge in different aspects of ICT). Therefore, the instrument was considered reliable because the Cronbach's Alpha reliability coefficient for all sub-scales was above 0.70 in all aspects.

Table 3. Testing the Cronbach's Alpha item-reliability coefficients of the subscales $(\mathrm{N}=60)$

\begin{tabular}{lccc}
\hline \multicolumn{1}{c}{ Sub-scale } & $\begin{array}{c}\text { No. of test } \\
\text { items }\end{array}$ & Cronbach $\alpha$ \\
\hline $\begin{array}{l}\text { 1.Students' skill and competences on } \\
\text { commonly used ICTs tools and } \\
\text { software }\end{array}$ & 20 & 0.875 \\
$\begin{array}{l}\text { 2.Students' attitude towards ICTs } \\
\text { and their belief regarding its }\end{array}$ & 29 & 0.857 \\
$\begin{array}{l}\text { usefulness } \\
\text { 3.Students' knowledge in different }\end{array}$ & 9 & .837 \\
aspects of ICTs
\end{tabular}

Out of 246 respondents participated in the entire survey questionnaire, $48 \%$ (118) were male students and 52\% (128) were female students which show a good gender balance among respondents. Table 4 shows that $75.2 \%(185)$ responded on the section of students' skills and commonly used ICT tools and software and 24.8\%(61) questionnaires were invalid, $67.5 \%(166)$ was a valid response under students' attitude towards ICT and their belief regarding its usefulness and $32.5 \%(80)$ questionnaires were invalid, $91.5 \%(225)$ was a valid response under students' knowledge in different aspects of ICT and 8.5\%(21) questionnaires were invalid. The following Likert scale interpretation was used for describing the means of items agreement in order to evaluate the students' skills, knowledge and attitudes on the use of ICT.

$\begin{array}{lc}\text { Strongly Agree } & 4.50-5.00 \\ \text { Agree } & 3.50-4.49 \\ \text { Moderate } & 2.50-3.49 \\ \text { Disagree } & 1.50-2.49 \\ \text { Strongly Disagree } & 1.00-1.49\end{array}$


Table 4. Respondents to student's skills, attitudes and knowledge towards ICTs $(\mathrm{N}=246)$

\begin{tabular}{lcc}
\hline \multicolumn{1}{c}{ Sub-scale } & $\mathrm{N}$ & $\%$ \\
\hline $\begin{array}{l}\text { Students' skill and competences on } \\
\text { commonly used ICTs tools and software }\end{array}$ & 185 & 75.2 \\
$\begin{array}{l}\text { Students' attitude towards ICTs and their } \\
\text { belief regarding its usefulness }\end{array}$ & 166 & 67.5 \\
$\begin{array}{l}\text { Students' knowledge in different aspects } \\
\text { of ICTs }\end{array}$ & 225 & 91.5 \\
\hline
\end{tabular}

The responses from participants were tabulated and compared and represented graphically. The descriptive analysis using Means, Standard Deviation and the $p$-value were done to present the details about the students' skills and competences on commonly used ICTs tools; students' attitude towards ICT and their belief regarding its usefulness and students' knowledge in different aspects of ICT. Furthermore, t-test statistics was used to test the four hypotheses formulated in the study.

\section{Results and Discussions}

\subsection{Students' Skills and Competences on Commonly Used ICT Tools and Software}

The general results as shown in Figure 1 indicates that, students' skills and competence on commonly used ICT tools and software (such as Internet services, web-browsers, mailing, animations, simulation, spreadsheet, Microsoft word and power-points) is between weak and moderate. This result concurs with the findings made by Hairulliza et al[20] who carried out a study to determine the students' computer literacy level among Malaysian secondary school. According to Hairulliza et al.[20], students' ICT skills were found to be between moderate and weak. However, Lujara[25] and Kalinga [31] shows that the use of ICT resources has not been utilized fully for learning and teaching processes in Tanzania Secondary schools. This under-utilization of ICT resources is attributed by a number of factors, including only small number of students using computer during their primary education [73][61].

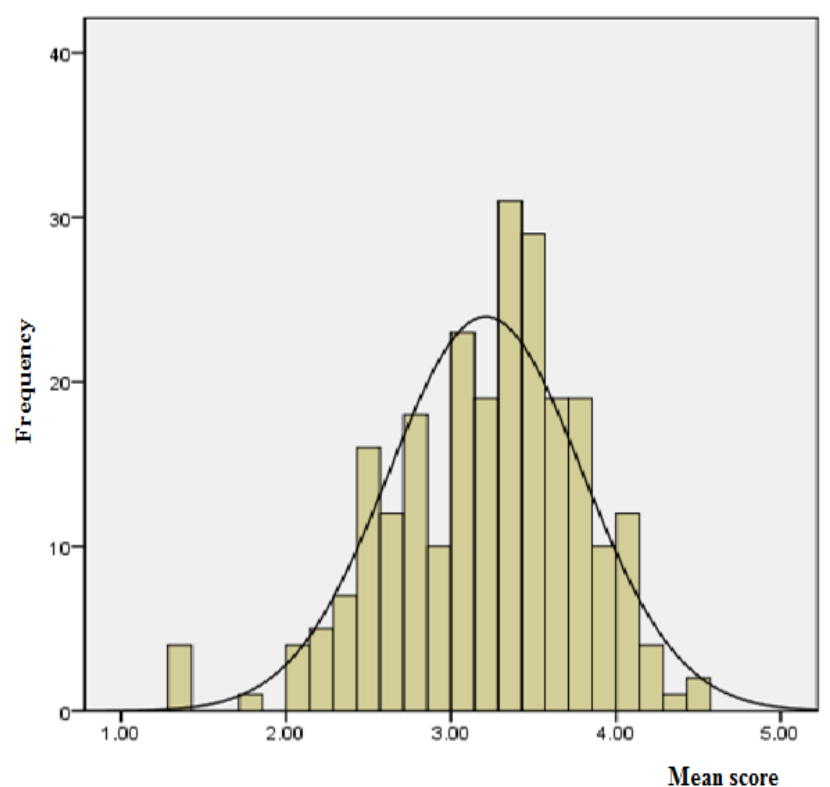

Figure.1. Students' skills and competences on commonly used ICT tools and software (i.e. Overall mean score $=3.21, \mathrm{Std}=.585$ )

\section{Hypothesis 1: There is no significant difference between ICT skills of male and that of female students in their academic life.}

Further analysis was conducted to study whether male and female students had different level of competences towards using ICT resources. Results (Table 5) show that male students have more skills and are competent in using some selected services offered by ICTs than females (i.e. $3.44>3.00)$. This was indeed supported by the $\mathrm{p}$-value being less than a significant value of $5 \%$ (i.e. $p<0.05$ ) leading to an acceptance that, there is a significant difference between male and female students regarding their skills and competences on commonly used ICT tools and software. From this, the null hypothesis was not accepted. However, this concurs with Sanga et.al [61] who highlighted that when there are limited ICT resources to be allocated to students and gender is not considered then male students is the group which have more benefit in accessing ICT resources.

Table 5. T-Test Analysis (Comparison regarding student's skills, attitudes and their knowledge on the use of ICTs in their academic life.

\begin{tabular}{|c|c|c|c|c|c|c|}
\hline Item & Gender & $\mathrm{N}$ & Mean & Std. Deviation & P-value & \\
\hline \multirow{2}{*}{$\begin{array}{l}\text { Students' skills and competence } \\
\text { to use ICTs }\end{array}$} & Male & 118 & 3.44 & .39 & \multirow{2}{*}{0.000} & \multirow{2}{*}{ Significant } \\
\hline & Female & 128 & 3.00 & .65 & & \\
\hline \multirow{2}{*}{$\begin{array}{l}\text { Attitude of students towards } \\
\text { usefulness of a ICTs secondary- } \\
\text { schools }\end{array}$} & Male & 117 & 3.82 & .49 & \multirow{2}{*}{0.000} & \multirow{2}{*}{ Significant } \\
\hline & Female & 128 & 3.42 & .46 & & \\
\hline \multirow{2}{*}{$\begin{array}{l}\text { Knowledge of students to use } \\
\text { ICT in different ways }\end{array}$} & Male & 116 & 3.61 & .80 & \multirow{2}{*}{0.140} & \multirow{2}{*}{ Non Significant } \\
\hline & Female & 128 & 3.50 & .73 & & \\
\hline
\end{tabular}

*p significant at 0.05 level* $^{*}$ 


\subsection{Students' Attitude towards ICT and Their Beliefs Regarding Its Usefulness}

Figure 2 shows mean score was 3.61 and standard deviation of students' attitude towards ICT and their belief regarding its usefulness in the selected PSS was 0.515.This results indicate that, students have high attitudes towards ICT use. The results are in line with Ariffin[85] who found that students from Kubang Pasu district in Malaysia have positive attitudes towards ICT use. Smith and Oosthuizen [86] found similar results in their survey conducted among entry-level students' attitudes towards computer use in South Africa. The results from their survey indicated that entry-level students had a greater appreciation on the benefits of computer use in learning.

\section{Hypothesis 2: There is no significant difference between the attitude of male and that of female students on the use of ICTs in their academic life.}

The T-Test analysis (Table 5) shows that male students have a mean score 3.82 and female students have a mean score of 3.42. This indicates that male students in the selected PSS have positive attitudes towards ICTs and they believe in the usefulness of computers in their academic life than female students. The p-value also shows that there is a significant difference between male and females (i.e. $p<0.05$ ) in attitude towards ICT and their beliefs regarding its usefulness. Based on this fact, the null hypothesis was not accepted.

Male students agree with positive attitudes while female students agree with moderate attitudes that:

a) ICT skills are very important for students in secondary school.

b) ICT makes teaching and learning more easy and interesting.

c) ICT makes it easier to obtain learning materials.

d) ICT has a human financial impact and is a sign of development of any nation

e) ICT makes students work more effective and they prefer to work with computers over manual.

f) ICT improves communications and enable to constantly learn new things.

g) ICT allows better jobs and improves the quality of life and makes life more convenient.

h) ICT allows students to have access to more education information and always want to know about the latest technologies.

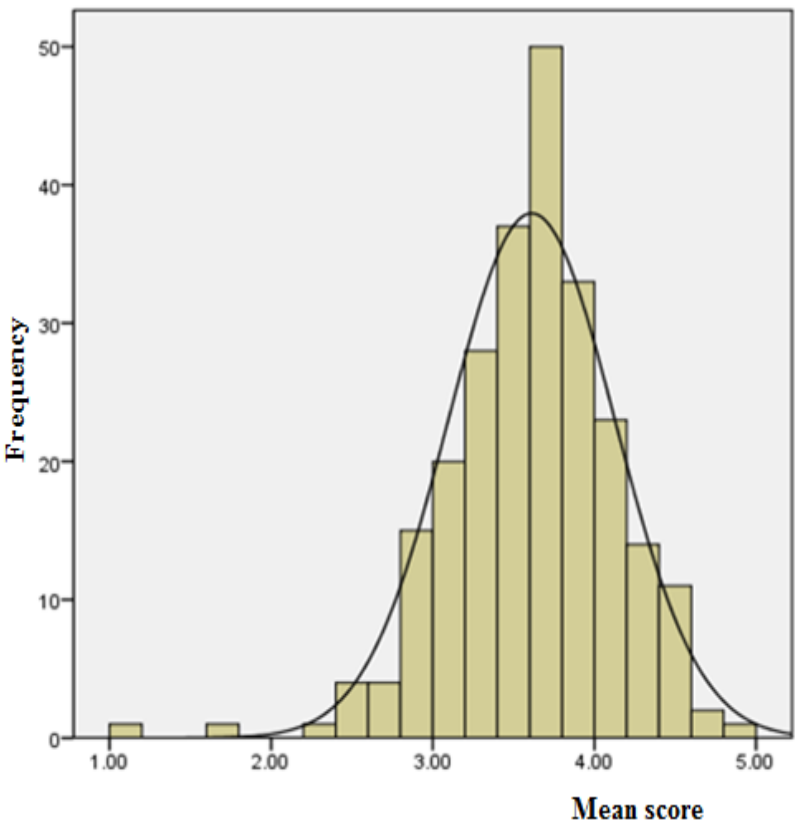

Figure 2: Students' attitude towards ICT and their belief regarding its usefulness (i.e mean score $=3.61$, $\mathrm{Std}=0.515$ ).

The moderate attitudes of female students towards ICTs and computer usefulness might be attributed to a number of factors. According to Sanga et al.[61], some of the factors include: male students are very motivated, committed, more favored and interested in learning more ICT knowledge and have more time to access computers than female students. In addition, male students might have less social responsibilities compared to female students. These results are contrary to those reported by Mudasiru et al.[45] who found that there was no significant difference between male and female students' attitude towards ICTs. Previous studies highlights that experience and constant use of ICTs to students are some of key factors to influence attitudes of students towards being motivated to use ICT in the teaching and learning processes[3][1][9][13][81][43][53].

\subsection{Students' Knowledge in Different Aspects of ICTs}

Fig. 3 shows that, the mean score was 3.53 and standard deviation of students' knowledge in different aspects of ICTs in the selected PSS was 0.767 . Table 5 also shows the T-test analysis of male and female was with mean score of 3.61 and mean score of 3.50 respectively. 


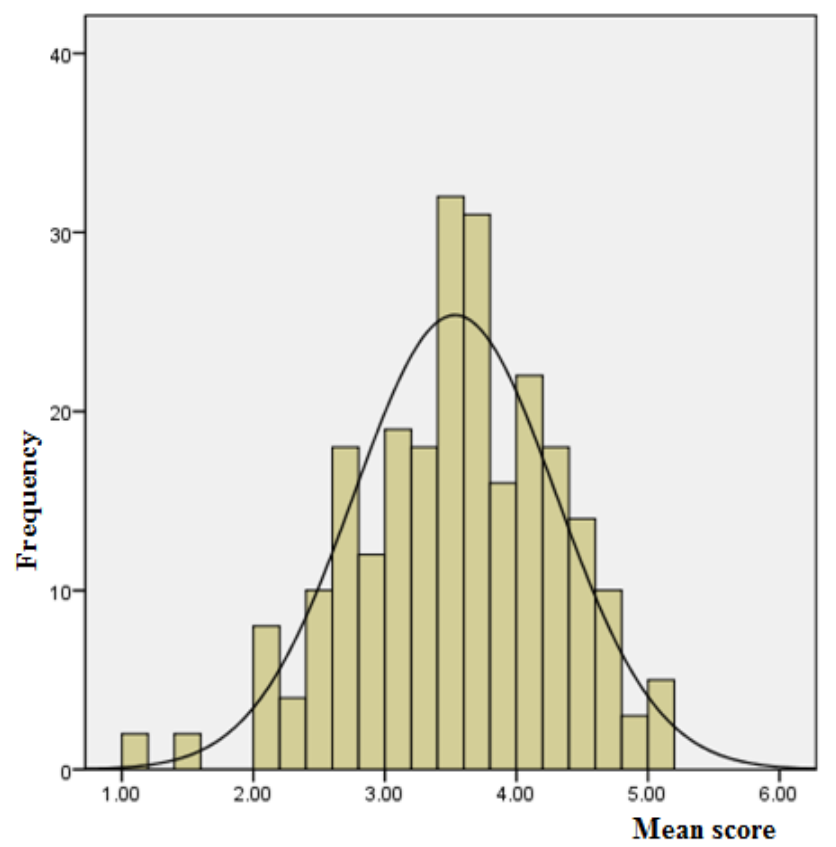

Figure 3. Students' knowledge in different aspects of ICTs (i.e. mean score $=3.53, \mathrm{Std}=0.676$ )

Hypothesis 3: There is no significant difference between the knowledge of male and that of female students on the use of ICTs in their academic life

These results indicate that male students have more knowledge regarding different aspects of ICTs than female students, though in general, there are no significant difference between male and female students regarding ICT knowledge (i.e. overall mean score was 0.353 ). The p-value in this sub-scale was more than $5 \%$ which shows that, there is no significant difference between male and female students regarding their knowledge in different aspects of ICTs ( $p>0.05)$. This knowledge was attributed to:

a) Knowing some mobile network operators like Tigo, Airtel, Vodacom and Zanteloperating in Tanzania

b) Knowing more than 10 radio and Television Broadcast companies operating in Tanzania c) knowing about Internet Service Provider (ISP) and the meaning of “.ac", “.com”, ,.edu”, ”org”, ,.net", ,.org”.

d) Knowing about uniform resource locator (URL) and more than 5 community tele-centres (or Internet café) that can be easily accessed.

\subsection{Perception of O-level and A-level Secondary School Students' Skills, Attitudes and their Knowledge on ICTs}

Researchers attempted to ascertain whether O-level and A-level students' population had any perception on their skills, attitudes and knowledge in the usefulness of ICT for teaching and learning.

\section{Hypothesis 4: There is no significant difference between the attitude, skills and knowledge of $\mathrm{O}$-level and that of A-level students on the use of ICTs}

The investigation results on association between O-level and A-level respondents on ICT usage are shown using T-test analysis in Table 6. Both O-level and A-level students have moderate skills and competence in using ICTs with a mean score 3.12 and 3.27 respectively. The results indicate that, O-level and A-level students have no significant difference in their skills and competence in using ICTs. Therefore, the null hypothesis was accepted. On the other hand, A-level students indicate to have positive attitudes towards the usefulness of ICTs with a mean score of 3.69 than O-level students with mean score of 3.49. This indicates a significant difference between the attitude of O-level and A-level students towards the usefulness of ICTs.

The p-value also shows that, there is a significant difference between O-level and A-level students in their attitudes towards usefulness of ICTs (i.e. $\mathrm{p}<0.05$ ). However, with the p-value of 0.93 , this result indicates that, the knowledge of O-level students (with mean score of 3.54) and A-level students (with mean score of 3.53) in different ways of using ICTs is high and there is no significant difference between their knowledge in different aspects of ICTs.

Table 6. T-Test Analysis (Comparison of O-level and A-level students' skills, attitudes and their knowledge on ICT).

\begin{tabular}{|c|c|c|c|c|c|c|}
\hline Item & Grade Level & $\mathrm{N}$ & Mean & Std. Deviation & $\mathrm{P}$-value & Remarks \\
\hline \multirow{2}{*}{$\begin{array}{l}\text { Students' skills and competence to } \\
\text { use ICTs }\end{array}$} & O-level students & 101 & 3.12 & .54 & \multirow{2}{*}{0.053} & \multirow[b]{2}{*}{ Non significant } \\
\hline & A-level students & 145 & 3.27 & .61 & & \\
\hline \multirow{2}{*}{$\begin{array}{l}\text { Attitude of students towards } \\
\text { usefulness of a ICTs secondary- } \\
\text { schools }\end{array}$} & O-level students & 101 & 3.49 & .54 & \multirow{2}{*}{0.002} & \multirow{2}{*}{ Significant } \\
\hline & A-level students & 144 & 3.69 & .48 & & \\
\hline \multirow{2}{*}{$\begin{array}{l}\text { Knowledge of students to use ICT } \\
\text { in different ways }\end{array}$} & O-level students & 100 & 3.54 & .81 & \multirow{2}{*}{0.930} & \multirow{2}{*}{ Non significant } \\
\hline & A-level students & 144 & 3.53 & .74 & & \\
\hline
\end{tabular}

*significant at 0.05 level* 


\subsection{Challenges Affecting Students' Effective Use of ICTs for Learning}

Students highlighted challenges affecting the use of ICTs for learning in secondary schools. Also, ICT teachers/trainers and school planning officers through interviews pointed out a number of factors that attribute to poor implementation and integration of ICT tools in PSS. Through observations and review of relevant documents, researchers were able to identify some factors inhibiting the ICTs implementations in selected PSS. However, a number of challenges and factors are within students' ability, some are institution's cases and others are contributed by the Government [61][35].This means some are internal and others are external factors. The following are the challenges / factors hindering ICT integration in PSS highlighted out by students, ICT teachers/Trainers and school planning officers:

a) The available courses of ICT in Tanzania PSS education system for A- level and O-level are inadequate and do not provide relevant ICT skills and knowledge to students.

b) Poor strategies, management and inadequate computers in students' computer laboratories as a result, some computers are not working.

c) Many remote areas in Tanzania have no access to the national power grid which in turn becomes difficult for secondary schools in those rural areas to own ICT infrastructure.

d) Computer illiteracy and lack of funds to purchase their own computers as many students argued that they come from poor families.

e) No Internet connections in many schools' computer labs which results in poor student's skills on information search skills on Internet.

f) Limited information sharing among students and among ICT teachers,

g) Lack of strategies for ICT integration in schools and shortage of ICT teachers and technicians due to the fact that, the number of ICT teachers and technicians graduating from TTCs don't meet PSS needs.

h) There is lack of strategies and policy framework for
ICT adoption in secondary schools

i) There is inadequate of in-service training on ICT.

j) There is an inadequate fixed telephone network infrastructures and the cost of the Internet is still high such that many PSS cannot afford. This is for the case of schools in remote areas where there is no even Telecommunications Company' towers'.

k) There is a very low emphasis regarding ICT training in secondary and primary school levels in Tanzania due to limited ICT facilities. In addition, most private schools (e.g. Feza Boys, Pandahill, Msolwa and Canossa) secondary schools with good ICT infrastructure and competent ICT staff are the ones that teach computer skills effectively [47].

Some informants or stakeholders believe that factors affecting students towards fully integration of ICTs for learning in selected PSS are contributed by not only technical factors, but also economic and political factors, social and cultural factors (e.g. corruptions, low teachers' beliefs). Also, the low advocacy of national ICT curriculum and other school-related factors greatly influence the integration of ICT in PSS. In order to address the mentioned factors there is a need of a holistic approach. However a holistic approach to ICT integration goes beyond the technological dimension [71] (Table 7) with a number of components that forms an end -to-end model or system. According to the International best practice, the end-to-end model

"addresses the key components of policy and planning, infrastructure and deployment, curriculum and content, training and usage, maintenance, support, monitoring and evaluation that provides for a comprehensive approach and an enabling environment for ICT integration" [71].

Therefore, in order to have a significant impact of ICT on students' learning in PSS, the following challenges related to deployment and integration of ICT have to be examined and find out to what extent deployment of ICT4E in Tanzania, specifically in PSS, can be implemented by including all the components of the end-to-end system. 
Table 7. Key Challenges related to deployment and integration of ICT in PSS (Adapted from Swarts \& Washira[71].

\begin{tabular}{|c|c|c|c|}
\hline $\begin{array}{l}\text { End to end } \\
\text { Element }\end{array}$ & Current status & Major challenges or gaps & Implications \\
\hline $\begin{array}{l}\text { Policy and } \\
\text { strategy }\end{array}$ & $\begin{array}{l}\text { - Strategies and ICT } \\
\text { policies already drafted and } \\
\text { aligned to the national } \\
\text { development plans and } \\
\text { goals. }\end{array}$ & $\begin{array}{l}\text { - Lack of unified framework and } \\
\text { strategy for education } \\
\text { - Lack of coordination between } \\
\text { schools and the ministry of } \\
\text { education. } \\
\text { - Limited capacity for implementing } \\
\text { the existing policies and strategies } \\
\text { - No guidance and support to } \\
\text { schools to implement strategy. }\end{array}$ & $\begin{array}{l}\text { - Ministries and institutions are unable to leverage work } \\
\text { and strengths of others. } \\
\text { - Initiatives normally end up in just duplicating and } \\
\text { waste useful resources. } \\
\text { - Harmonized implementation would accelerate } \\
\text { progress, complement other initiatives and maximize } \\
\text { impact. Limited information sharing and knowledge } \\
\text { expertise and teaching experiences } \\
\text { - Studies indicate that schools with ICT plans and good } \\
\text { strategies do use ICT effectively in school settings. }\end{array}$ \\
\hline $\begin{array}{l}\text { Deployment of } \\
\text { ICTs in PSS }\end{array}$ & $\begin{array}{l}\text { Institutional e-readiness } \\
\text { - Schools use the available } \\
\text { ICT resources for teaching } \\
\text { basic computer skills. } \\
\text { - Distribution of ICT } \\
\text { facilities in PSS is not a } \\
\text { priority due to limited } \\
\text { funds from the } \\
\text { Government. } \\
\text { ICT equipment and } \\
\text { software in PSS } \\
\text { - Computer laboratories are } \\
\text { used as the model for } \\
\text { equipping students with the } \\
\text { necessary ICT skills. } \\
\text { - There is no available data } \\
\text { to indicate the state of ICTs } \\
\text { in PSS except Teacher' } \\
\text { Colleges (TC). } \\
\text { Connectivity and } \\
\text { electricity } \\
\text { - Higher Learning } \\
\text { Institutions(HLIs) and all } \\
\text { Governmental TCs have } \\
\text { Internet connectivity and } \\
\text { are connected to the } \\
\text { National electricity power } \\
\text { grid, but very few PSS are } \\
\text { connected } \\
\text { - The national Fiber Optic } \\
\text { Cable have improved the } \\
\text { telecommunications } \\
\text { infrastructure }\end{array}$ & $\begin{array}{l}\text { PSS e-readiness } \\
\text { - No researches have been done to } \\
\text { explore PSS e-readiness and } \\
\text { baseline data on school' e-readiness } \\
\text { in Tanzania. } \\
\text { ICT equipment and software } \\
\text { - There are no strategies and } \\
\text { affordable solutions for purchasing } \\
\text { ICT resources in PSS. } \\
\text { - The priority for deploying ICT } \\
\text { facilities is on teacher's education. } \\
\text { - ICT students' skills, knowledge } \\
\text { and training are limited by relying } \\
\text { on the use of computer lab model in } \\
\text { all PSS. } \\
\text { Connectivity and electricity } \\
\text { - The limited and high cost of } \\
\text { bandwidth to most PSS. } \\
\text { - The integration and use of ICT in } \\
\text { remote PSS is mainly constrained by } \\
\text { the lack of electricity. } \\
\text { - No other means to provide } \\
\text { electricity in remote PSS like the use } \\
\text { of power generators. }\end{array}$ & $\begin{array}{l}\text { Institutional e-readiness } \\
\text { - Inability of PSS to take the Internet connectivity } \\
\text { advantages in communicating, collaborating and sharing } \\
\text { the available ICT resources. } \\
\text { - PSS are not using ICT effectively in order to enhance } \\
\text { the teaching and learning processes. ICTs are not used } \\
\text { also to provide students with the necessary skills to } \\
\text { students that are required in the twenty first century. } \\
\text { - Because of unavailability of e-readiness data in PSS, it } \\
\text { becomes difficult to plan and deploy ICT facilities in } \\
\text { PSS. } \\
\text { ICT equipment } \\
\text { - Sustainability of ICT facilities in PSS is a challenge } \\
\text { because of depending on donors in acquiring these ICT } \\
\text { facilities. } \\
\text { - ICT facilities cannot be fully utilized in PSS if there are } \\
\text { no clear goals that drive educational deployment models. } \\
\text { - There is a need to conduct studies that will provide a } \\
\text { comparison and contrast between different deployment } \\
\text { options and models based on PSS educational objectives. } \\
\text { - Without uniform and specifications for acquiring the } \\
\text { required ICT resources, then PSS are likely to acquire } \\
\text { unfit resources for use in teaching and learning process. } \\
\text { Connectivity and electricity } \\
\text { - The current fiber optic cable and } 3 \mathrm{G} \text { technologies in } \\
\text { Tanzania provide new opportunities of reduced Internet } \\
\text { connectivity costs in many PSS. }\end{array}$ \\
\hline $\begin{array}{l}\text { Technical } \\
\text { Support and } \\
\text { Maintenance }\end{array}$ & $\begin{array}{l}\cdot \text { No specific models which } \\
\text { are used in PSS to provide } \\
\text { ICT facilities, maintenance } \\
\text { and support. } \\
\text { •No maintenance and } \\
\text { technical support in } \\
\text { secondary schools. }\end{array}$ & $\begin{array}{l}\text { - There is no comprehensive } \\
\text { maintenance and support strategy } \\
\text { from the MoEVT. } \\
\text { - No ICT unit in MoEVT dedicated } \\
\text { for the maintenance of equipment at } \\
\text { MoEVT and in PSS. }\end{array}$ & $\begin{array}{l}\text { - In most PSS where there are ICT resources, these } \\
\text { resources are not fully utilized because most of the time } \\
\text { the computes laboratories are locked. } \\
\text { - There are should be some mechanisms for providing } \\
\text { technical support and maintenance, especially in PSS } \\
\text { located in remote areas. }\end{array}$ \\
\hline $\begin{array}{l}\text { ICT training } \\
\text { For teachers }\end{array}$ & $\begin{array}{l}\text { - TCs are the first priority in } \\
\text { building capacity for ICT. } \\
\text { - Many TTCs have } \\
\text { introduced ICT training } \\
\text { courses for pre-service } \\
\text { teachers. } \\
\text { - All TTCs have integrated } \\
\text { ICT subject in their } \\
\text { curriculum. }\end{array}$ & $\begin{array}{l}\text { - Little emphasis in adopting the } \\
\text { teacher's pedagogical development } \\
\text { framework regarding the integration } \\
\text { and use of ICT in PSS. } \\
\text { - No strategies towards using ICTs } \\
\text { as significant tools in e-learning in } \\
\text { PSS. }\end{array}$ & $\begin{array}{l}\text { - Most of the ICT4E initiatives in PSS have no a clear } \\
\text { coordination with intended school which affect students } \\
\text { in acquiring the relevant ICT skills. } \\
\text { - Lack of enough knowledge and skills for secondary } \\
\text { school teachers to use ICT in improving their } \\
\text { teaching and student learning }\end{array}$ \\
\hline
\end{tabular}




\begin{tabular}{|c|c|c|c|}
\hline $\begin{array}{l}\text { End to end } \\
\text { Element }\end{array}$ & Current status & Major challenges or gaps & Implications \\
\hline $\begin{array}{l}\text { Content and } \\
\text { curriculum }\end{array}$ & $\begin{array}{l}\text { Curriculum } \\
\text {-TCs, } \\
\text { Educational and Training } \\
\text { Applications (VETA) and } \\
\text { HLIs already have ICT } \\
\text { syllabuses for guiding in } \\
\text { the teaching and learning } \\
\text { process. } \\
\text { No emphasis on the } \\
\text { importance of using ICTs } \\
\text { for teaching and learning at } \\
\text { all levels of the education } \\
\text { sector in Tanzania. } \\
\text { - Currently, examination } \\
\text { results from primary to } \\
\text { HLIs are uploaded online. } \\
\text { PSS also register their } \\
\text { candidates online and link } \\
\text { directly with the MoEVT } \\
\text { database } \\
\text { Digital content } \\
\text { - The efforts to develop the } \\
\text { digital content are very } \\
\text { limited. }\end{array}$ & $\begin{array}{l}\text { Curriculum } \\
\text { - Although the ICT syllabus is } \\
\text { available in TTCs, but still teacher's } \\
\text { ICT skills are very low. } \\
\text { - The integration of ICT in teaching } \\
\text { and learning is hindered by a lack of } \\
\text { clear and common framework as } \\
\text { guidance in the process of ICT } \\
\text { integration in PSS } \\
\text { - The existing curriculum has not } \\
\text { been reviewed to be in line with the } \\
\text { twenty first century. } \\
\text { Digital content } \\
\text { - E-learning in PSS is constrained by } \\
\text { high cost of bandwidth. }\end{array}$ & $\begin{array}{l}\text { Curriculum } \\
\text { - The use of ICT by teachers and students is mainly } \\
\text { limited by lack of digital content. } \\
\text { - Without clear ICT policies and curriculum in place } \\
\text { which emphasize ICT integration in PSS, then, it will be } \\
\text { very difficult to integrate ICTs in secondary schools } \\
\text { which could also affect the teaching and learning } \\
\text { transformation process. } \\
\text { - The number of teachers graduating from TTCs does not } \\
\text { meet PSS needs. } \\
\text { Digital content } \\
\text { - PSS still have a big challenge due to absence of digital } \\
\text { content which affect the delivery and access of relevant } \\
\text { ICT skills and knowledge. }\end{array}$ \\
\hline $\begin{array}{l}\text { Monitoring, } \\
\text { evaluation and } \\
\text { Management, }\end{array}$ & $\begin{array}{l}\text { - Educational data are being } \\
\text { collected by MoEVT } \\
\text { through the EMIS } \\
\text { department. } \\
\text { - Statistics also concerning } \\
\text { educational matters from } \\
\text { all regions are produced. }\end{array}$ & $\begin{array}{l}\text { - PSS has no common framework } \\
\text { for administering and supporting the } \\
\text { implementation and coordination of } \\
\text { EMIS functionalities among } \\
\text { schools. } \\
\text { - The monitoring and evaluation } \\
\text { process in ICT4E initiatives is very } \\
\text { limited, but the new strategy TBT } \\
\text { can help to some extent. }\end{array}$ & $\begin{array}{l}\text { - Educational challenges related to quality, equity and } \\
\text { ICT are constrained by poor school administrations. } \\
\text { - The wastage of ICT equipment resulted from } \\
\text { under-utilization of ICTs which then reduce the positive } \\
\text { impact on the process of learning and teaching in PSS. } \\
\text { - Lack of Monitoring and Evaluation impose difficulties } \\
\text { in determining how ICT can play in transforming } \\
\text { learning and teaching process so that it can be easy to } \\
\text { adjust policies and strategies accordingly. }\end{array}$ \\
\hline
\end{tabular}

\subsection{Institutional Strategies to Increase Use of ICTs in PSS}

Although all selected secondary schools indicated to have computer laboratories, the use of computers in these schools is very low. The respondents suggested the following strategies in order to increase the use of ICTs in PSS.

a) Improving ICT infrastructure in PSS so as to accommodate all students and staff by providing more computers in the computer laboratories which need to have Local Area Networks (LANs) connected with reliable Internet.

b) The Government of Tanzania should establish a National ICT Innovation and Incubation Centre (NIIIC) which should have a mandate of promoting students learning and sharing ICT innovative skills among students and harnessing the ever growing needs for ICT solutions through local entrepreneurs in ICT.

c) Provide continuous in-service teachers training in ICT courses and PSS teachers should encourage and motivate students to use ICT4E.

d) In order to equip PSS students with self-directed learning and personalized learning, then they should be exposed to Computer Assisted Learning (CAL) or e-learning or mobile learning or virtual learning so as to motivate problem based learning (PBL) in all education levels .

e) The PSS should employ and adapt e-learning based on either problem based learning or action research learning or experiential learning or personalized learning to complement face-to-face learning and teaching (talk \& chalk teaching) processes. The application of e-learning 2.0 (i.e. integration of web 2.0 tools and e-learning) is very significant in improving the learning and teaching processes in PSS. The e-learning 2.0 enable students to access more learning materials which can reduce the shortage of learning materials in many PSS.

f) Develop and implement educational policy which focuses on ICT4E in PSS.

\section{Conclusions and Future Work}

The findings revealed that students, teachers and school administrators perceived that the use of ICT in secondary schools in this knowledge economy era is of great importance and inevitable. This finding is similar to what Sedoyeka and Gafufen[65] found in their study titled 'Computers in Tanzania Secondary Schools-Challenges and Opportunities'. Also, the finding is similar to what Muhoza et al.[46] reported. However, our study differentiates from previous studies by presenting the students' viewpoints 
rather than teachers' viewpoints as it were reported in many previous studies [2].Also, this study presents its findings in disaggregated data by sex. It shows that male students have more skills and competence in using ICTs tools for learning than female students. This lack of skills and competency to female students is attributed by low access to ICT resources proportionally as male's students. It is also due to some gender factors such as male students are very motivated, committed, more favored and interested in learning more ICT knowledge than female students. Also, male students in secondary schools have positive attitudes towards ICTs than female students whose attitudes were found to be moderate, and they believe in the usefulness of ICTs in their academic life than female students. This is similar to what Sanga et al.[61] found in study done to investigate if e-learning can motivate female students in learning science, technology, engineering and mathematics (STEM).

The results from this study have indicated that, students have more knowledge regarding different aspects of ICTs. This knowledge is attributed to knowing the mobile network operators in Tanzania, radios and Television broadcasting technologies operating in Tanzania, Internet Service Provider (ISP), and community tele-centres. Ordinary secondary school level (O-level) and Advanced secondary school level (A-level) students' skills are moderate, with A' level students' attitudes rated high than that of O-level students while the knowledge of ICT in different aspects of both O-level and A-level students was found to be high. This indicates that if the integration and adoption of ICT in PSS is well planned, implemented and managed; it will ensure the delivery of an intended outcome from advanced electronic learning framework for students and teachers [31].

Some of challenges that affects students towards the use of ICTs for learning in PSS include: inadequately courses of ICTs available in Tanzania PSS system of education for both A-level and O-level students; poor strategies, management and limited number of computers in students' computer laboratories, poor ICT infrastructure, inadequate of in-service training on ICT, the cost of Internet is high for schools management; computer illiteracy and lack of funds from their families to purchase their own computers.

Researchers suggest some strategies which can enhance the use of ICTs in PSS in Tanzania. These strategies include: improve and build computer laboratories that should have local area network connected with reliable Internet in all PSS; The Government of Tanzania should develop and open a National ICT Innovation and Incubation Centre (NIIIC) with the mandate of promoting students learning and sharing ICT innovative skills among students; in-service staff training in ICT courses and their involvement in encouraging students to use ICT in their studies; The PSS should employ and adapt e-learning so that schools can substitute the current face-to-face learning and teaching processes. The suggestions from this paper can address some of the challenges listed in Table 7.

The impact of ICT for PSS education in Tanzania is more critical today because of its high growth rate and its capability to trigger changes in teaching and learning environments[16].The rapid penetrations and increased use of mobile phones in Tanzania can be used to complement face-to-face learning and e-learning with mobile learning in PSS. The use of ICT in PSS will offer enabling environments that can transform the learning and teaching processes so that learners/students can be equipped with relevant knowledge in self-directed, constructive and an active problem based learning. By implementing, integration and innovative use, ICT4E can facilitate student-centered learning[14][34] enabling students to engage in a constructivist classes and therefore enhancing their social interaction[12]; increase their creativity; improve their cognitive development and problem solving skills[52].

Future study should replicate this research to find out if the findings from this study can be generalized. The future study should be guided by diffusion theory[59][70].The essence should be to test generalization of the findings from this study as well as to test if the results would support and confirm Roger's adoption and innovation curve(Fig.4).

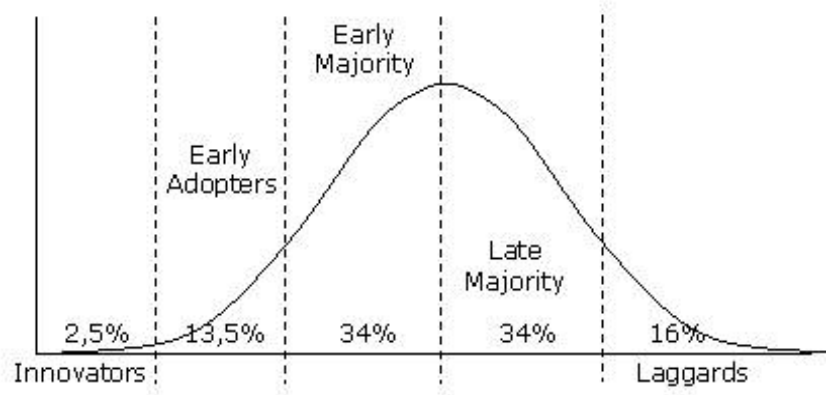

Figure 4. Roger's Bell Curve of Potential Adopters, Rogers [70].

According to the literature review, not much is documented about ICT in primary schools (Hennessy et $\mathrm{al}[23]$ and thus replication of this paper in setting of primary schools can also be an area for future study.

\section{Recommendations}

This study provides an evident that, ICT has a positive impact on PSS education; it has been implemented in some of the schools aiming at enabling schools to improve their learning and teaching processes. The findings from this study enabled authors to make the following recommendations:

a) Education stakeholders who have relevant professional development skills and knowledge regarding ICTs should effectively integrate ICT in PSS. There is a need to equip education stakeholders who are involved in teaching (in-service and pre-service teachers, principals) with the importance and role of technology before starting teaching students in classrooms. This professional development should be created in a collaborative and participatory manner, based on training institutions inputs and PSS needs. In addition, the in-service 
training should be an ongoing exercise so that learners/teachers can be in line with the current changing technological.

b) Different actors in the education value chain (i.e. Government of Tanzania, students, parents, teachers, school administrators and the whole community) need to have a strong awareness and commitment on the potential of ICTs in developing students' learning. Also, there should be ways of overcoming the challenges that hinder the use of new technologies for learning and teaching in PSS settings. This is important so that students can benefit effectively from emerging ICTs. The commitment in the implementation of ICT should be done with a clear vision of ICT integration in PSS. This need to be shared with all members of the school community in order to have a great promotion, uptake and up scaling and thus, enhances the effective use of ICT in the schools.

c) The PSS should formulated strategies and ICT policies inclined with those of the Government. The policies and implementation plan need to be gender sensitive.

d) The Government of Tanzania through the MoEVT and COSTECH should encourage and motivate local IT companies to design software that can support use of ICT in the teaching and learning processes. However, these companies should work together with secondary school teachers on how to design appropriate learning management systems for students in all PSS.

e) PSS should establish educational technology unit in each secondary school. Also there is need of sensitization on importance of ICT for learning in secondary schools. This should be continuous and PSS should have ICT policies and programmes for gender equity relating to the use of ICT in education. However, outstanding students in ICT subjects should be given incentives such as awards and scholarships, which will encourage male and female students to study hard ICT and related STEM subjects. In addition, providing career guidance and mentoring in PSS, enabling students to adapt ICT curriculum, and high interaction of teachers and students will enhance efficient integration of ICT in PSS education.

f) The Government of Tanzania must have initiatives towards establishing rural Community Information Centers (CIC) which will be of use to all citizens including secondary school students in rural areas. The proposed CIC need to be evaluated, monitored and maintained regularly. Also, CIC should be assessed on how they enhance teaching and learning of ICT programs in PSS. The aim is to ensure they are effective, efficiency and efficacy in promoting ICT4E.

\section{REFERENCES}

[1] Alexander, M. E., et al. 2010, 'Using the four-questions technique to enhance critical thinking in online discussions', Journal of Online Learning and Teaching, vol. 6, no. 2, pp. 409-415.

[2] Albirini, A. (2006). Teachers' attitudes toward information and communication Anne technologies: The case of Syrian EFL teachers. Computers \& Education, 47(4), 373-398. Samson,(2013),"Tanzania Education Affairs "[Online] Available at http://www.tzaffairs.org/2013/01/education-3/.

[3] Baek, Y.G., Jong, J., \& Kim, B. (2008). What makes teachers use of technology in the classroom? Exploring the factors affecting facilitation of technology with a Korean sample. Computers and Education, vol.50, no. 8, pp. 224-234

[4] Bangert, A. (2008). 'The influence of social presence and teaching presence on the quality of Online critical inquiry', Journal of Computing in Higher Education, vol. 20, no. 1, pp. 34-61.

[5] Black, T. R. (1999). Doing quantitative research in the social sciences: An integrated approach to research design, measurement, and statistics. Thousand Oaks, CA: SAGE Publications, Inc. (p. 118).

[6] Blignaut, R. J., Venter, I. M., \& Stoltz, D. (1998). Chalk-And-Talk versus Cooperative Learning. A Comparative Study. In Teleteaching (pp. 139-148).

[7] Blum, L., Frieze, C., Hazzan, O. et al. (2007). "A cultural perspective on gender diversity in computing". Retrieved from http://www

2.cs.cmu.edu/ lblum/PAPERS/CrossingCultures.pdf.

[8] Burniske, R. (2001). Avaricious and envious: confessions of a computer-literate educator. Phi. Delta Kappan, 82: 524-527.

[9] Cavas, B., et al. 2009, 'A study on science teachers' attitudes toward information and communication technologies in education', The Turkish Online Journal of Educational Technology vol. 8, no. 2, pp. 20-32.

[10] Czaja. R., Blair, J., Blair, E., \& Field, A. P. (2014). Designing surveys: a guide to decisions and procedures. Thousand Oaks: SAGE,[2014].

[11] De Corte, E., Verschaffel, L., Entwistle, N., \& van Merrienboer, J. (Eds.). (2003).’Powerful learning environments, unraveling basic components and dimensions. Oxford", Pergamon/Elsevier.

[12] Dodge, D., Colker, L., \& Heroman, C. (2003). The creative curriculum for preschool. Washington, DC: Teaching Strategies.

[13] Dogan, M. 2010, 'Primary trainee teachers' attitudes to and use of computer and technology in mathematics: The case of Turkey', Educational Research and Review vol. 5, no. 11, pp. 690-702.

[14] Drent, M. (2005). In Transitie: Op Weg Naar Innovatief ICT-gebruik op de PABO [In transition: On the road to innovative use of ICT in teacher education] (doctoral dissertation). Enschede: University of Twente. 
[15] Duveskog, M., Sutinen, E., Tedre, M., \& Vesisenaho, M. (2003, November). In search of contextual teaching of programming in a Tanzanian secondary school. In FRONTIERS IN EDUCATION CONFERENCE (Vol. 2, pp. F3B-9). STIPES.

[16] Evoh, C. (2007, March 20). Policy networks and the transformation of secondary education through ICTs in Africa: The prospects and challenges of the NEPAD e-Schools initiative. International Journal of Education and Development using ICT [Online], 3(1)

[17] Farrell, G., \& Isaacs, S. (2007). "Survey of ICT and Education in Africa". A Summary Report, Based on 53 Country Surveys. Washington, DC: infoDev/ World Bank.

[18] Furuholt, B., \& Kristiansen, S. (2007). A rural-urban Digital Divide? Regional aspects of Internet use in Tanzania. The Electronic Journal of Information Systems in Developing Countries, 31

[19] GovTz.(1999).The Tanzania Development Vision 2025 Government of the United Republic of Tanzania Dar es Salaam.

[20] Hairulliza, M.J.; Hazilah, M.A; Nor Azan, M.Z. and Rodziah, L.Rural Students' Skills and Attitudes Towards Information and Communication Technology; Journal of Social Sciences 7 (4): 619-626, 2011; ISSN 1549-3652 (C) 2011 Science Publications.

[21] Hakkarainen, K., Ilomäki, L., Lipponen, L., Muukkonen, H., Rahikainen, M., Tuominen, T., Lakkala, M., \& Lehtinen, E. (2000). Students' skills and practices of using ICT: Results of a national assessment in Finland. Computers and Education,34, 2, 103-11.

[22] Hare, H. 2007. "Survey of ICT and Education in Africa": Tanzania Country Report. World Bank, Washington, DC. C World Bank.

https://openknowledge.worldbank.org/handle/10986/10648 License: CC BY 3.0 Unported."

[23] Hennessy, S., Harrison, D., \& Wamakote, L. (2010). Teacher factors influencing classroom use of ICT in Sub-Saharan Africa. Itupale online journal of African studies, 2(1), 39-54.

[24] Hindi, N.M., Miller, D. and Wenger, J. (2002). Computer literacy: Implications for teaching a college- level course. J. Inform. Syst. Edu., 13: 143-151.

[25] Hooker, Esther Mwiyeria \& Anubha Verma, 2011," ICT Competency Framework for Teachers in Tanzania: Teacher Development for the 21st Century (TDev21) pilot", A Ministry of Education and Vocational Education Tanzania, World Bank and GESCI Initiative.

[26] ICT4E, 2007. MoEVT ICT Policy for Basic Education http://www.moe.go.tz/pdf/MoEVT ICT Policy for Basic Education. Retrieved on 3rd June, 2014.

[27] Intelecon Research and Consultancy ltd. (2005)," Universal Access and Universal Service Funds: insights and experience of international best practice"[ Online] Available at http://www.inteleconresearch.com/pdf/050713\%20\%20univ ersal $\% 20$ access $\% 20$ and $\% 20$ universal $\% 20$ service $\% 20$ funds $\% 20 \mathrm{v} 3 . p d f$

[28] Intelecon Research and Consultancy ltd(2009)," Universal Access and Universal Service Funds:", Updated October 2009.
[29] Johnson, R. B., \& Onwuegbuzie, A. J. (2004). Mixed methods research: A research paradigm whose time has come. Educational researcher, 33(7), 14-26.

[30] Santos, J. Reynaldo A. (1999)," Cronbach's Alpha: A Tool for Assessing the Reliability of Scales", Journal of Extension, Vol.37, No 2, ISSN 1077-5315[Online] available at http://www.joe.org/joe/1999april/tt3.php.

[31] Kalinga, A. E., Bagile, B., \& Trojer, L. (2007). An interactive e-Learning management system (e-LMS): A solution to Tanzanian secondary schools' education. World Academy of Science, Engineering and Technology, 3(19), 109-112.

[32] Cantafio.K (2010)," About Tanzania Beyond Tomorrow:" [Online] available at

$\mathrm{http}: / /$ kelvincantafio.ca/nethope/tanzania-beyond-tomorrow/

[33] Komba, W. (2009, October 24). Increasing education access through open and distance learning in Tanzania: A critical review of approaches and practices. International Journal of Education and Development using ICT [Online], 5(5). Available: http://ijedict.dec.uwi.edu/viewarticle.php?id=859.

[34] Lujara, S. K., Kissaka, M. M., Trojer, L., \& Mvungi, N. H. (2006). Introduction of open-source e-learning environment and resources: A novel approach for secondary schools in Tanzania. International Journal of Social Sciences, 1(4).

[35] Lujara, S. K. (2008). Development of e-Learning Content and Delivery for Self Learning Environment: Case of Selected Rural Secondary Schools in Tanzania. School of Technoculture, Humanities and Planning, Blekinge Institute of Technology.

[36] Mafu, S. (2004). From the oral tradition to the information era: The case of Tanzania. International Journal on Multicultural Societies, 6(1), 53-78.

[37] Mbaeze, I. C. Elochukwu Ukwandu, Choima Anudu. (2010). "The Influence of Information and Communication Technologies on Students' Academic Performance", Journal of Information Technology Impact, Vol. 10, No. 3, pp. 129-136.

[38] Mgaya,K.V. (1994)." Development of information technology in Tanzania" Information Technology in selected Countries: Report From Ireland, Ethiopia, Nigeria, and Tanzania[Online] available at http://www.tanzaniagateway.org/docs/development of infor mation_techno_in_tanzania.pdf

[39] Miller. J., Kartano, K., Ntiro, S. (2004). ICT investment Opportunities in East Africa: Country Specific Market Analysis - Tanzania, International Finance Corporation. Retrieved November 20, 2006, from www.trigrammic.com/downloads/new2005/Tanzania\%20Re port.pdf.

[40] MoCT. (2003). National information and communications technologies policy, Ministry of Communication and Transport, The United Republic of Tanzania, Dar es Salaam.

[41] MoEVT. (2007). Information and Communication Technology (ICT) Policy for Basic Education; ICT for Improved Education.

[42] MoEVT.( 2011),"A list of Non-Governmental and Governmental Registered Secondary Schools in Tanzania", Registered up to African Union(AU),[Online] available at http://www.moe.go.tz/index.php?option=com_docman\&Ite 
$\operatorname{mid}=621$.

[43] Moore, K. \& Iida, S. 2010, 'Students' perception of supplementary, online activities for Japanese language learning: Group work, quiz and discussion tools', Australasian Journal of Educational Technology, vol. 26, no. 7, pp. 966-979.

[44] Mwalongo, A.(2011), 'Teachers' perceptions about ICT for teaching, professional development, administration and personal use", International Journal of Education and Development using Information and Communication Technology(IJEDICT), 2011, Vol. 7, Issue 3, pp. 36-49.

[45] Mudasiru O. Yusuf, Modupe R. Balogun. (2011). Student-Teachers' Competence and Attitude towards Information and Communication Technology: A Case Study in a Nigerian University; CONTEMPORARY EDUCATIONAL TECHNOLOGY, 2011, 2(1), 18-36.

[46] Muhoza, O. U., Tedre, M., Aghaee, N., \& Hansson, H. (2014, April). Viewpoints to ICT Practices and Hindrances from in Tanzanian Secondary Schools and Teacher Training Colleges: Focus on Classroom Teachers. In Teaching and Learning in Computing and Engineering (LaTiCE), 2014 International Conference on (pp. 133-140). IEEE.

[47] National Examination Council of Tanzania (NECTA).(2013).” Certificate of Secondary Examination

Results 2013”, [Online] available at http://www.necta.go.tz/ matokeo_html_2013/CSEE2013/olevel.htm.

[48] Ndibalema, P. (2014).Teachers' Attitudes towards the Use of Information Communication Technology (ICT) as a Pedagogical Tool in Secondary Schools in Tanzania: The Case of Kondoa District, International Journal of Education and Research, 2(2), 1-16.

[49] Nir-Gal, O., \& Klein, P. (2004). Computers for cognitive development in early childhood - The teacher's role in the computer-learning environment. Information Technology in Childhood Education Annual, 16, 97-119.

[50] Nunnaly, J. (1978). Psychometric theory. New York: McGraw-Hill Nyirenda, M. (2013). Planning for ICT literacy in public schools in Tanzania. URL

http://www.ippmedia.com/frontend/?1=62206.

[51] Onwuegbuzie, A. J., et al. (2009). "Mixed data analysis: Advanced integration techniques" International Journal of Multiple Research Approaches, vol. 3, no. 1, pp. 13-33.

[52] O'Hara, M. (2008). Young children, learning and ICT: A case study in the UK maintained sector. Technology, Pedagogy and Education, 17(1), 29-40.

[53] Ottenbreit-Leftwich, A. T., et al. (2010), 'Teacher value beliefs associated with using technology: Addressing professional and student needs', Computers \& Education, vol. 55, no. 3, pp.1321-1335.

[54] Pajo, K., \& Wallace, C. (2001). "Barriers to the uptake of web-based technology by university teachers" Journal of Distance Education, 16, 70-84.

[55] Plomp. Tj., ten Brummelhis, A.C.A., \& Rapmund, R. (1996). "Teaching and Learning for the Future", Report of the Committee on MultiMedia in Teacher Training (COMMITT), Den Haag: SDU.

[56] Pulkkinen, J. (2007). "Cultural globalization and integration of ICT in education". In K. Kumpulainen (Ed.), Educational technology: Opportunities and challenges (pp.13-23). Finland: University of Oulu.

[57] Rathgeber, E. M. (2000). Women, men and ICTs in Africa: Why gender is an issue. Gender and the information revolution in Africa, 17-34.

[58] Reagle, J. (2012). "“Free as in sexist?" Free culture and the gender gap", First Monday, vol. 18, no.1.

[59] Rogers, E. M. (2010). Diffusion of innovations. Simon and Schuster.

[60] Sanga, C., Magesa, M., \& Kayunze, K. (2011). "E Learning Technology-enabling Science Education to Female Students: e Learning-enabling Science Education to Female Students in Developing Countries: The Case Study of Tanzania Universities": LAP Lambert Academic Publishing AG \& Co KG.

[61] Sanga, C. ; Magesa, M.M. ; Chingonikaya, E. and.Kayunze; K.A. (2013). Can e-learning promote participation of female students in STEM disciplines in higher learning institutions of Tanzania? International Journal of Education and Development using Information and Communication Technology (IJEDICT), Vol. 9, Issue 3, pp. 86-102.

[62] Sarama, J., \& Clements, D. (2001). Computers in early childhood mathematics. Paper presented at the American Educational Research Association, Panel Discussion, Seattle, WA.

[63] Saunders, M.N.K., Lewis, P., \& Thornhill, A. (2009). Research Methods for Business Students (5th ed.). Harlow, United Kingdom: FT Prentice Hall.

[64] Sedoyeka, E. (2012). Obstacles in bridging the digital divide in Tanzania. International Journal of Computing and ICT Research, 6(1), 60-72.

[65] Sedoyeka, E., \& Gafufen, G. (2013). Computers in Tanzania Secondary Schools-Challenges and Opportunities. International Journal of Computing \& ICT Research, 7(1). pp 22-32.

[66] Senzige, J. \& Sarukesi, K. (2003) 'An approach to ICT based school education in Tanzania', African Studies Association of Australasia and the Pacific - African on a Global Stage, pp.

[67] Sife, A., Lwoga, E., \& Sanga, C. (2007). New technologies for teaching and learning: Challenges for higher learning institutions in developing countries. International Journal of Education and Development using ICT, 3(2).

[68] Simba, F., Trojer, L., Mvungi, N. H., Mwinyiwiwa, B. M., \& Mjema, E. M. (2009). Strategies for Connectivity Configuration to Access e-Learning Resources: Case of Rural Secondary Schools in Tanzania. Communities, 10, 11.

[69] Simba, F. (2010). Modeling Connectivity for e-Learning in Tanzania: Case-study of Rural Secondary Schools.

[70] Surry, D. W., \& Farquhar, J. D. (1997). Diffusion theory and instructional technology. Journal of Instructional Science and Technology, 2(1), 24-36.

[71] Swarts, P. and Wachira, E.M. (2010). ICT in Education Situational Analysis in Tanzania; Global e-schools and Communities Initiatives (GeSCI), available at http:/gesci.org/assets/files/Knowledge\%20Centre/Situationa 1\%20Analysis_Tanzania.pdf. 
[72] Tanzania Students Website/Wanafunzi -Tanzania.(2010). available at

http://www.iicd.org/projects/tanzania-wanafunsi/?searchterm $=$ None.

[73] Tedre, M., Ngumbuke, F., \& Kemppainen, J. (2010). "Infrastructure, Human Capacity, and High Hopes: A Decade of Development of e-Learning in a Tanzanian HEI", Redefining the Divide in Higher Education, vol. 2, no. 7, pp. 7-20.

[74] Tilya, F. (2007). ICT in education in Tanzania: Lessons and experiences from IICD-supported projects, International Institute for Communication Development, The Hague.

[75] Unwin, T. (2005). 'Towards a framework for the use of ICT in teacher training in Africa', Open Learning, vol. 20, no. 2, pp. $113-129$.

[76] United Nations Educational Scientific and Cultural Organization (UNESCO) (2008) ICT Competency Standards for Teachers: Implementation Guidelines [Online], available from UNESCO

at:http://unesdoc.unesco.org/images/0015/001562/156209E. pdf,retrieved 11 April 2009.

[77] United Republic of Tanzania (URT). (2003). National Information and Communications Technologies Policy [Online], available at: http://www.tanzania.go.tz/pdf/ictpolicy.pdf.

[78] United Republic of Tanzania (URT).(2006). "The Universal Communications Service Access act, 2006"[Online] availablehttp://www.ucaf.go.tz/downloads/UCSA\%20Act.pd f.
[79] Venter, I. M., Blignaut, R. J., \& Stoltz, D. (2000). Tailoring IT Education for Effective IT Professionals in a Third World Setting. ECIS 2000 Proceedings, 39.

[80] Volman, M., \& Van Eck, E.(2001). "Gender Equity and Information Technology in Education", the Second Decade. Review of Educational Research, 71(4), 613-634.

[81] Von Konsky, B., et al. (2009). 'Lecture attendance and web based lecture technologies: A comparison of student perceptions and usage patterns', Australasian Journal of Educational Technology, vol.25, no. 4, pp. 581-595.

[82] Voogt, J., Tilya, F., \& van den Akker, J. (2009). Science teacher learning of MBL-supported student-centered science education in the context of secondary education in Tanzania. Journal of Science Education and Technology, 18(5), 429-438.

[83] Wamakote, L., Ang'ondi, E. K., \& Onguko, B. (2010). East African governments' investments in information and communication technologies for education: Matching policy to practice. Itupale Online Journal of African Studies, 2, 25-38.

[84] World Summit on the Information Society (Geneva).( 2003). (Tunis, 2005) WSIS Declaration of Principles and WSIS Action Plan [Online], available at:

http://www.itu.int/wsis/documents/doc_multi.asp?lang=en\&i $\mathrm{d}=1161 \% 7 \mathrm{C} 1160$, retrieved 18 March 2011 .

[85] Ariffin, T.F.B.T., 2005. Gender differences in computer attitudes and skills. J. Pendidikan, 30: 75-91.

[86] Smith, E., \& Oosthuizen, H. J. (2006). Attitudes of entry-level University students towards computers: a comparative study. Computers and Education, 47 (3), 352-371 